\title{
Protein phosphatase $1 \gamma$ regulates the proliferation of human glioma via the NF-кB pathway
}

\author{
ZHEN BAO ${ }^{1}$, CHENGWEI DUAN ${ }^{2}$, CHENG GONG $^{3}$, LIANG WANG ${ }^{3}$, \\ CHAOYAN SHEN $^{2}$, CHENG WANG ${ }^{2}$ and GANG CUI ${ }^{1}$ \\ ${ }^{1}$ Department of Neurosurgery, The First Affiliated Hospital of Soochow University, Suzhou; ${ }^{2}$ Jiangsu Province \\ Key Laboratory for Inflammation and Molecular Drug Target, Medical College of Nantong University; \\ ${ }^{3}$ Department of Gastroenterology, Affiliated Hospital of Nantong University, Nantong, Jiangsu, P.R. China
}

Received November 26, 2015; Accepted December 23, 2015

DOI: $10.3892 /$ or.2016.4644

\begin{abstract}
Protein phosphatase $1 \gamma(\mathrm{PP} 1 \gamma)$, a member of mammalian protein phosphatases, serine/threonine phosphatases, catalyzes the majority of protein dephosphorylation events and regulates diverse cellular processes, such as neuronal signaling, muscle contraction, glycogen synthesis, and cell proliferation. However, its expression and potential functions in human glioma is unclear. In this study, we detected the high expression of PP1 $\gamma$ and phosphorylated p65 (p-p65) in human glioma tissues. Besides, we demonstrated that upregulation of PP1 $\gamma$ was tightly related to poor 5-year survival via systemic statistical analysis. Employing serum-starved and re-feeding models of U251 and U87MG, we observed the increasing expression of PP1 $\gamma$ and p-p65 were accompanied by the cell proliferation markers cyclin D1 and proliferating cell nuclear antigen (PCNA). Employing depletion-PP1 $\gamma$ models, we found downregulated PP1 $\gamma$ and p-p65 compared with upregulated $\mathrm{I} \kappa \mathrm{B} \alpha$, which indicates the inhibition of $\mathrm{NF}-\kappa \mathrm{B}$ pathway, and flow cytometry analysis confirmed the weakened cell proliferation. Moreover, we found that the translocation of p65 into the nucleus was impaired. Collectively, we identified the positive correlation between upregulation of PP1 $\gamma$ and human glioma cell proliferation and that knock-down of PP1 $\gamma$ alleviated the glioma proliferation by reducing p65 transportation into the nucleus. The results showed that PP1 $\gamma$ could accelerate human glioma proliferation via the $\mathrm{NF}-\kappa \mathrm{B}$ pathway.
\end{abstract}

\section{Introduction}

Human neural glioma, the most lethal brain tumor and the most frequent type of primary adult brain neoplasms, has dismal outcome for patient (1-3). Patients diagnosed with glioma have

Correspondence to: Professor Gang Cui, Department of Neurosurgery, The First Affiliated Hospital of Soochow University, Suzhou, Jiangsu, P.R. China

E-mail: cuigang120@sina.com

Key words: human glioma, $\mathrm{PP} 1 \gamma, \mathrm{NF}-\kappa \mathrm{B}, \mathrm{p} 65$, proliferation a very low 5-year survival, compared with patients affected by glioblastoma multiforme (GBM) $(4,5)$. Despite significant advances in neurosurgery and chemo-radiotherapy, glioma remains highly resistant to conventional treatments and improvements in patient outcome have been modest (6). For this reason, it is vital and urgent to investigate thoroughly the molecular pathological mechanism, for some more specific biomarkers and potential remedy targets.

Protein phosphatase 1 (PP1) is a member of the wellknown mammalian protein phosphatases, serine/threonine phosphatases, which catalyzes the majority of protein dephosphorylation events that regulate diverse cellular processes, such as neuronal signaling, muscle contraction, glycogen synthesis, and cell proliferation. Mammals have three PP1 catalytic genes, PP1 $\alpha, \gamma$ and $\delta$, which are encoded by separate genes. These isoforms are $>89 \%$ identical in amino acid sequence, with minor differences primarily at their $\mathrm{NH} 2$ and $\mathrm{COOH}$ termini (7). The equivalent $\mathrm{T}$ residue is conserved in all three PP1 isoforms (T316 in PP1 $\beta$ and T311 in PP1 $\gamma$ ), and PP1 $\gamma$ can be inactivated by Cdk-dependent T311 phosphorylation. PP1 $\alpha$ and/or - $\beta$ could compensate for the depletion of PP1 $\gamma$ in development, but not in the specific function of spermiogenesis. PP1 $\gamma$ has two isoforms, $\gamma 1$ and $\gamma 2$, generated by differential splicing of PP1 $\gamma$. PP1 isoforms are expressed in all tissues and are widely distributed, except for PP1 $\gamma 2$, which is found only in the testes. Mice with depleted PP1 $\gamma$ are viable, but males show defective spermiogenesis and are infertile (8). Thus, in this study, we focused on PP1 $\gamma 1$.

The transcription factor, nuclear factor-kappa $\mathrm{B}(\mathrm{NF}-\kappa \mathrm{B})$, plays an important role in tumor cells. Constitutive activation of $N F-\kappa B$ is responsible for proliferation, because inhibition of NF- $\kappa B$ leads to abrogation of proliferation (9). In normal cells, most of $\mathrm{NF}-\kappa \mathrm{B}$ complexes are kept predominantly cytoplasmic, and stay in an inactive form, by binding to a family of inhibitor proteins, the IкBs. Generally, the inactive $\mathrm{NF}-\kappa \mathrm{B}-\mathrm{I} \kappa \mathrm{B} \alpha$ complex is activated by phosphorylation on two conserved serine residues within the $\mathrm{N}$-terminal domain of the I $\kappa$ B proteins (10). PP1 $\gamma$ enhances TRAF6 E3 ubiquitin ligase activity (11) and the induction of NF- $\kappa B$ activation (12). Subsequently, TRAF6 catalyzes the ubiquitin of IKK/NEMO (NF- $\kappa \mathrm{B}$ essential modulator) (11). IKK proteins coordinate the phosphorylation, ubiquitination, and degradation of inhibitory 
$\mathrm{I} \kappa \mathrm{B} \alpha$ proteins, liberating $\mathrm{NF}-\kappa \mathrm{B}$ heterodimers to translocate into the nucleus. Activation of the IкB kinase (IKK) complex results in the phosphorylation and subsequent proteasomal degradation of $\mathrm{I} \kappa \mathrm{B} \alpha(13)$. Activation of the NF- $\kappa \mathrm{B}$ signaling cascade results in complete degradation of $\mathrm{I} \kappa \mathrm{B}$, allowing translocation of $\mathrm{NF}-\kappa \mathrm{B}$ to the nucleus, where it induces transcription (14). Activated NF- $\kappa \mathrm{B}$ binds to specific DNA sequences in target genes involved in tumor cell proliferation, invasion, metastasis, angiogenesis, chemoresistance, radioresistance, inflammation and immunoregulation (10).

According to previous studies, PP1 $\gamma$ might promote tumor progression in colorectal cancer (15). Here, we identified the paralleled positive correlation between the expression of PP1 $\gamma$ and Ki-67 in human glioma tissue and cell lines, and the depletion of PP1 $\gamma$ reduced cell proliferation distinctly. Besides, we demonstrated PP1 $\gamma$ might accelerate the glioma cell proliferation via NF- $\kappa$ B pathway by enhancing the transportation of p65 into the nucleus. Based on the results, it might be a promising target for human glioma diagnosis and therapy in future.

\section{Materials and methods}

Patients and tissue specimens. The human glioma tissues were collected from 100 glioma surgical specimens without any therapy, and the clinicopathological data were provided by the Department of Pathology, Affiliated Hospital of Nantong University. Normal brain specimens obtained from 10 patients who received epilepsy surgery were verified for the absence of any tumor. Specimens were immediately frozen in liquid nitrogen and stored at $-80^{\circ} \mathrm{C}$ until use. Some parts of the specimens (including WHO grade II, III and IV) were fixed in $10 \%$ formalin and embedded in paraffin for immunohistochemical analysis. All the tissues were collected and applied in accordance with The Code of Ethics of the World Medical Association. Ethics approval was given by the medical ethics committee of the Affiliated Hospital of Nantong University.

Cell lines and cell culture. The human glioblastoma cell lines H4, SHG44, U87MG, U251, A172 and U373 were purchased from Shanghai Institute of Cell Biology. All cells were cultured in the DMEM high-glucose medium (Gibco BRL, Grand Island, NY, USA) with $10 \%$ heat-inactivated fetal bovine serum at $37^{\circ} \mathrm{C}$ with $5 \% \mathrm{CO}_{2}$.

Antibodies. The antibodies applied to immunohistochemistry included: anti- PP1 $\gamma$ (diluted 1:400, Santa Cruz Biotechnology), anti-Ki-67 (diluted 1:400, Santa Cruz Biotechnology). The antibodies applied to western blot analysis included: anti-PP1 $\gamma$ (diluted 1:2,000, Santa Cruz Biotechnology), anti-p65 (diluted 1:2,000, Santa Cruz Biotechnology), anti-p-p65 (S536-p, diluted 1:2,000, Cell Signaling Technology), anti-IкB $\alpha$ (diluted 1:2,000, Santa Cruz Biotechnology), anti-proliferating cell nuclear antigen (PCNA, diluted 1:1,000, Santa Cruz Biotechnology), anti-cyclin D1 (diluted 1:1,000, Santa Cruz Biotechnology), anti- $\alpha$-tubulin (diluted 1:1,000, Santa Cruz Biotechnology), anti-Lamin B (diluted 1:1,000, Santa Cruz Biotechnology), anti-glyceraldehyde-3-phosphate dehydrogenase (GAPDH, diluted 1:1,500, Santa Cruz Biotechnology).
Immunohistochemistry (IHC). The glioma tissues sections were deparaffinized in xylene, rehydrated in graded ethanol solutions, and then we block the endogenous peroxidase activity in $0.3 \%$ hydrogen peroxide. Then the sections were heated at $105^{\circ} \mathrm{C}$ in $0.1 \mathrm{M}$ citrate buffer, $\mathrm{pH} 6.0$ for $10 \mathrm{~min}$ and incubated at room temperature for $1 \mathrm{~h}$ to retrieve the antigen. Afterwards, the section were incubated with $5 \%$ bovine serum in PBS (phosphate-buffered saline) ( $\mathrm{pH}$ 7.2) for blocking nonspecific protein binding, followed by overnight incubation with appropriate antibodies at $4^{\circ} \mathrm{C}$. Negative-control groups were treated with non-specific immunoglobulin IgG (Sigma Chemical Co., St. Louis, MO, USA) as the first antibody. Then the sections were incubated. According to the manufacturer's instructions, the slides were rinsed in PBS and incubated with hematoxylin, dehydrated and mounted successively in resin mount (16).

Immunohistochemical evaluation. All of the stained sections were evaluated in a blinded manner by two independent senior pathologists without any clinicopathological variables of the patients (17). Five high-power fields (Leica microscope Germany) were selected randomly and $>300$ cells in each field were counted to determine the labeling index (LI), which means the percentage of immunostained cells relative to the total number of cells (18). Intensity was evaluated in comparison with the control and scored as follows: 0, negative staining; 1, weak staining; 2 , moderate staining; 3 , strong staining. The percentage of tumor cells stained positive was scored as follows: $0,<1 \%$ positive tumor cells; $1,1-10 \%$ positive tumor cells; $2,10-50 \%$ positive tumor cells; $3,50-75 \%$ positive tumor cells; $4,>75 \%$ positive tumor cells. Then we added the scores of intensity and percentage as 0 and 2-7. 0 , negative; 2-3, weak stained; 4-5, moderate stained; 6-7, strong stained. For statistical analysis, 0-3 were counted as low expression, while 4-7 were counted as overexpression (19).

Cellular fractionation. Cells were washed twice with phosphate-buffered saline (PBS), and resuspended in buffer A (50 mM NaCl, 10 mM HEPES, pH 8.0, $500 \mathrm{mM}$ sucrose, $1 \mathrm{mM}$ EDTA, $0.2 \%$ Triton X-100, $1 \mathrm{mM} \mathrm{NaF}, 0.5 \mathrm{mM} \mathrm{Na}_{3} \mathrm{VO}_{4}, 1 \mathrm{mM}$ PMSF, and $2 \mu \mathrm{g} / \mathrm{ml}$ aprotinin, $0.5 \mathrm{mM} 2$-mercaptoethanol) for 15 min on ice. Cells were homogenized with 20 strokes using a Dounce homogenizer. After brief centrifugation, the supernantant was collected as a cytoplasmic fraction and the pelleted nuclei was further washed three times with isotonic sucrose buffer $\left(250 \mathrm{mM}\right.$ sucrose, $6 \mathrm{mM} \mathrm{MgCl}_{2}, 10 \mathrm{mM}$ Tris- $\mathrm{HCl}$, $\mathrm{pH}$ 7.4) containing $0.5 \%$ non-ionic detergent Triton $\mathrm{X}-100$ to dissolve any cytoplasmic membrane contaminants (20). To extract nuclear proteins, the isolated nuclei were resuspended in buffer $\mathrm{C}$ (350 mM NaCl, 10 mM HEPES, pH 8.0, 25\% glycerol, $0.1 \mathrm{mM}$ EDTA, $1 \mathrm{mM}$ PMSF, and $2 \mu \mathrm{g} / \mathrm{ml}$ aprotinin, $0.5 \mathrm{mM} 2$-mercaptoethanol) with gentle rocking for $30 \mathrm{~min}$ at $4^{\circ} \mathrm{C}$. After centrifugation, the supernatant was collected as a nuclear fraction $(21)$.

Western blot assay. Glioma tissue samples were homogenized in lysis buffer (1\% Nonidet P-40, $50 \mathrm{mmol} / 1$ Tris, $\mathrm{pH}$ 7.5, 5 mmol/1 EDTA, 1\% SDS, $1 \%$ sodium deoxycholate, $1 \%$ Triton X-100, $1 \mathrm{mmol} / 1 \mathrm{PMSF}, 10 \mathrm{mg} / \mathrm{ml}$ aprotinin, and $1 \mathrm{mg} / \mathrm{ml}$ leupeptin). Cell samples were washed three times with 
PBS, suspended in $2 \mathrm{X}$ lysis buffer $(50 \mathrm{mM}$ Tris-HCl, $120 \mathrm{mM}$ $\mathrm{NaCl}, 0.5 \%$ Nonidet P-40, $100 \mathrm{mM} \mathrm{NaF}, 200 \mathrm{M} \mathrm{Na}_{3} \mathrm{VO}_{4}$, protease inhibitor mixture). Then, samples were denatured at $100^{\circ} \mathrm{C}$ for $15 \mathrm{~min}$ and evaluated with Bio-Rad protein assay (Bio-Rad, Hercules, CA, USA) for the total protein concentration, and then stored at $-20^{\circ} \mathrm{C}$. The protein samples were separated via SDS-polyacrylamide gel electrophoresis (SDS-PAGE) and transferred to polyvinylidene difluoride filter (PVDF) membranes (Millipore, Bedford, MA, USA). The membranes were blocked in TBST $(20 \mathrm{mM}$ Tris, $150 \mathrm{mM}$ $\mathrm{NaCl}, 0.05 \%$ Tween-20) with 5\% evaporated milk for $2 \mathrm{~h}$ at room temperature and then incubated in appropriate antibodies at $4^{\circ} \mathrm{C}$ for 6-8 $\mathrm{h}$. The membranes were washed with TBST for three times, $5 \mathrm{~min} /$ each time and incubated with horseradish peroxidase-linked IgG for $2 \mathrm{~h}$ at room temperature, and then detected by infrared imaging system (Odyssey, USA). The blot band intensity was quantified by ImageJ analysis file (Wayne Rasband, National Institutes of Health, USA) (22).

RNA interference of PPI $\gamma$. The PP $1 \gamma$-shRNAs were synthesized by GeneChem. PP $1 \gamma$-shRNAs target sequences: shRNA\#1, 5'-AATGCCACGAGACCTGTAA-3'; shRNA\#2, 5'-GAATT ATGCGACCAACTGA-3'; shRNA\#3, 5'-GACCGATTATGC TTTCTTT-3'; shRNA\#4, 5'-TGCTGTCATGGAGGTTTAT-3'. U251 cells were transfected with $100 \mathrm{nmol} / \mathrm{l}$ of shRNA\#2 performed with Lipofectamine 2000 (Invitrogen, Carlsbad, CA, USA) and U87MG cells with shRNA\#4. The cells were identified as negative-control groups treated with control shRNA, and the mock non-treated groups.

Flow cytometry analysis of cell cycle. Following the indicated pre-treatment, cells were fixed with $70 \%$ methanol in PBS at $-20^{\circ} \mathrm{C}$ for $48 \mathrm{~h}$, and then with $1 \mathrm{mg} / \mathrm{ml}$ RNase A for $20 \mathrm{~min}$ at $37^{\circ} \mathrm{C}$. Afterwards, the cells were stained with $0.5 \mathrm{mg} / \mathrm{ml}$ of propidium iodide (PI). The DNA contents were analyzed by a Becton-Dickinson flow cytometer, BD FACScan (San Jose, CA, USA).

Cell Counting Kit-8(CCK)-8. The cells transfected by shRNAs, with the untreated groups were seeded on a 96-well cell culture cluster (Corning Inc., Corning, NY, USA) at $2 \times 10^{4}$ cells/well in $100 \mu \mathrm{l}$ medium and incubated overnight. Cell Counting Kit-8 (Dojindo, Kumamoto, Japan) reagents were added to a subset of wells with different treatments, after which absorbance was measured at a test wavelength of $450 \mathrm{~nm}$ on an automated plate reader with the $630 \mathrm{~nm}$ wavelength as a reference group.

Colony formation assay. The selected and stably-transfected cells were plated in $6-\mathrm{cm}$ culture plates at 100 cells/well. After incubation for 12 days at $37^{\circ} \mathrm{C}$, the cells were washed twice with PBS and stained with Giemsa solution. The number of colonies containing $>50$ cells was counted under a microscope.

$N F-\kappa B$ activity assay. Nuclear extracts from U251 and U87MG cell lines, treated with conditioned media were prepared using the nuclear extract kit (Active Motif). Total protein amounts were measured by BCA-assay (Pierce, Rockford, IL, USA), NF- $\kappa B$ activity was measured using the TransAM NF- $\kappa B$ p65 assay kit according to the manufacturer's instructions. Briefly, $5 \mu \mathrm{g}$ of nuclear extract per sample was added to the 96-well plate, in which oligonucleotide containing the NF- $\kappa \mathrm{B}$ consensus site (5'-GGGACTTTCC-3') was immobilized. The active form of NF-kB bound to the oligonucleotide was detected using an antibody against NF- $\mathrm{KB}$ p65 subunit. An HRP-conjugated secondary antibody provided a sensitive colorimetric readout that was quantified by spectrophotometry.

Statistical analysis. Statistical analysis was performed by the SPSS17.0 statistical analysis software. The statistical correlations between PP1 $\gamma$ and Ki-67 expression and the clinicopathological features were analyzed using the $\chi^{2}$ test. Survival analysis was carried out using the Kaplan-Meier method, and curves were compared using the log-rank test. All of values were expressed as mean \pm SEM (standard error of the mean), and $\mathrm{P}<0.05$ was considered statistically significant.

\section{Results}

The correlation of the expression of PP1 $\gamma, p-p 65, p 65$ and $\mathrm{Ki}-67$ in human glioma tissues with the WHO grades of human glioma. For investigating the possible role of PP1 $\gamma$ in the development of glioma, we detected and compared the expression of PP1 $\gamma$, p-p65, p65 in normal brain tissues and three couples of glioma tissues in the rank of WHO grade II, III and IV by western blot analysis. According to statistical analysis, we observed significant rising tendency of PP $1 \gamma$ in normal brain tissues, low-grade and high-grade glioma tissues (Fig. 1A and B), as well as p-p65 and p65. Especially, the relative expression of p-p65 is decreased after being normalized to total $\mathrm{p} 65$. As an important reported proliferation marker, Ki-67 was examined in 100 specimens of human glioma tissues with PP $1 \gamma$ by immunohistochemical staining. It showed consistent correlation of the expression of Ki-67 and PP1 $\gamma$ (Fig. 1C and D), indicating that PP $1 \gamma$ was related to the proliferation of glioma cells. Then, we summarized the clinicopathological statistics and found the close relationship of PP1 $\gamma$ to WHO grades of glioma $(\mathrm{P}<0.01)$, and it was the same as Ki-67 used as cross reference (Table I). There was no obvious relevance to other clinicopathological factors. Based on this, we considered that PP $1 \gamma$ might have a great influence on the progression of glioma relatively, and its overexpression might lead to poor prognosis.

The relationship between the expression of PPI $\gamma$ in the specimens and the patient 5-year survival or the prognosis of human glioma. To verify the presumption, we carried out statistical analysis via SPSS. According to Kaplan-Meier survival curves, the patients with high expression of PP1 $\gamma$ had lower accumulative 5-year survival ratio $(\mathrm{P}<0.01)$. It was just the same as the impact of overexpression of Ki-67 (Fig. 1E and F). Subsequently, we employed the univariate survival analysis to compare the impact of other clinicopathological factors on the 5-year survive to that of PP1 $\gamma(\mathrm{P}<0.05)$ and Ki-67 $(\mathrm{P}<0.01)$, and we concluded that the overexpression of the two molecules was closely related to the poor prognosis of the glioma patients (Table II).

The expression of PPI $\gamma$ in glioma cell lines and the relationship to cell proliferation. To identify the function of PP1 $\gamma$ in pathological procession of glioma, we selected two glioma 
A

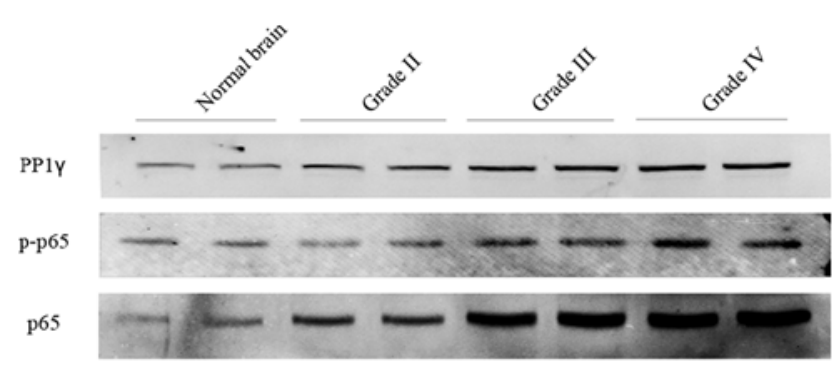

GAPDH

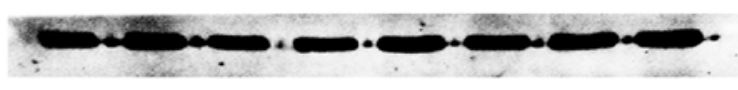

C

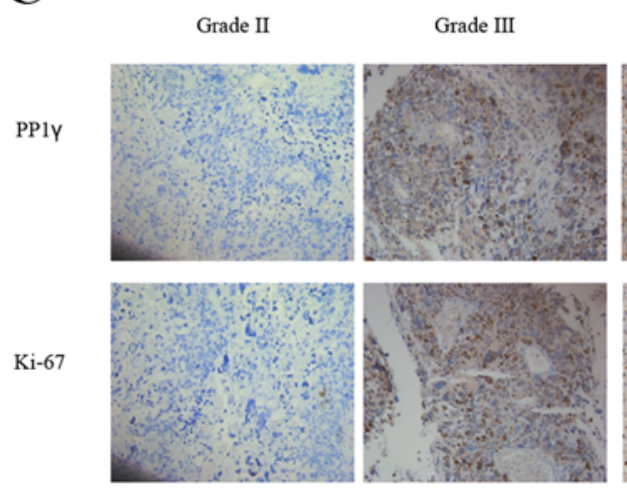

$\mathbf{E}$

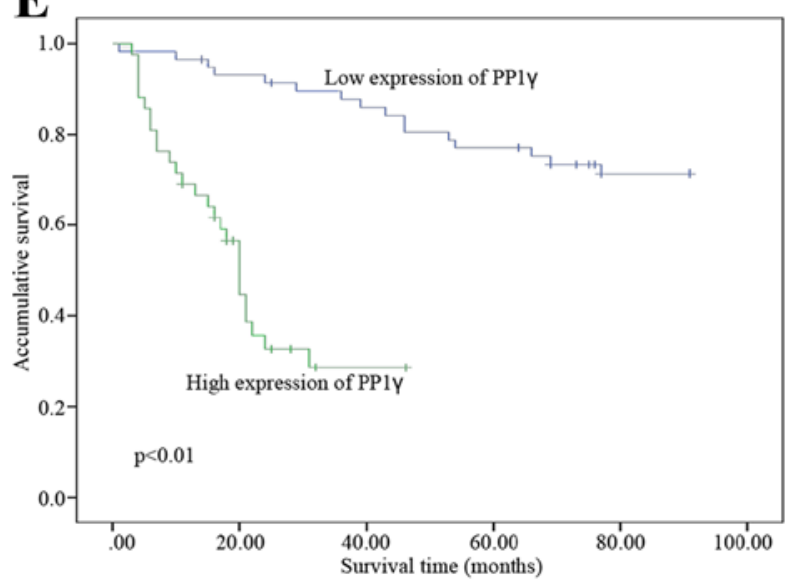

\section{G}

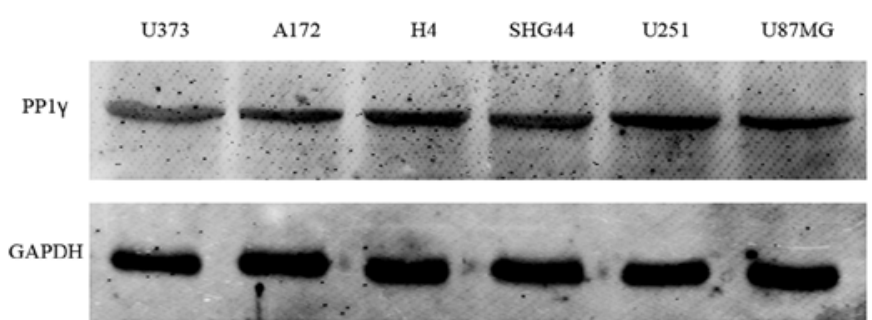

Grade IV
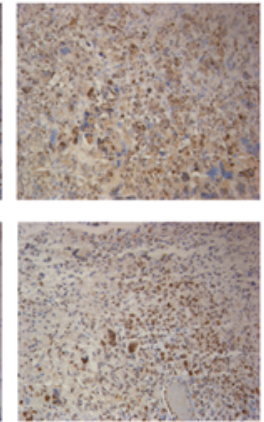

B

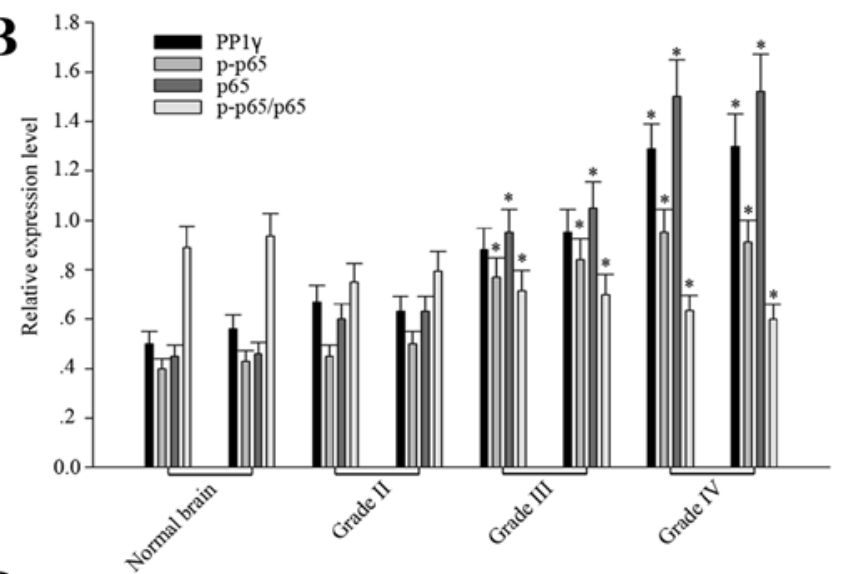

D

\section{$\mathbf{F}$}
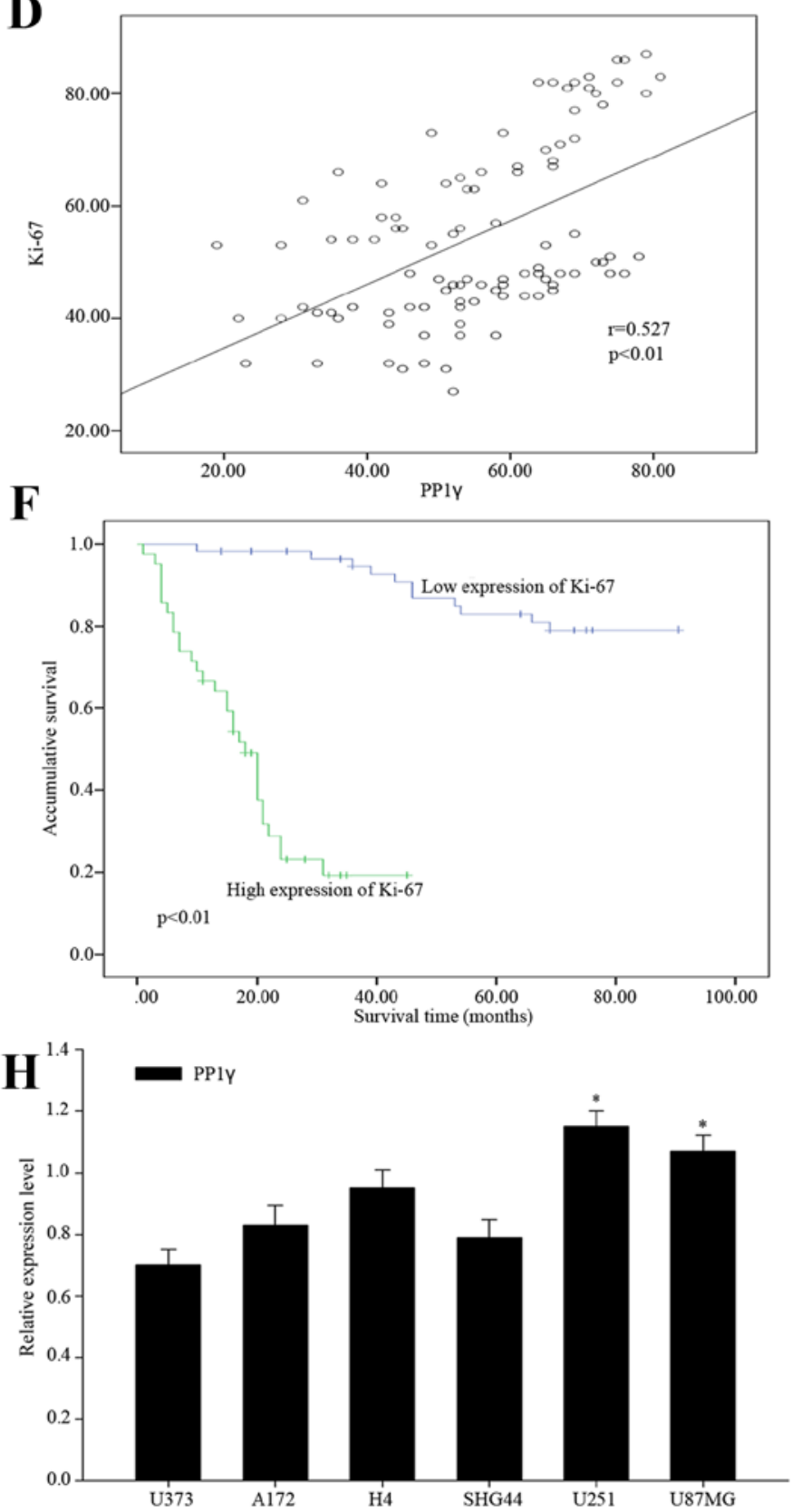

Figure 1. The overexpression of PP1 $\gamma$ and Ki-67 was detected in glioma tissues, and it is consistent with low accumulative survival. (A and B) Expression of PP1 $\gamma$, p-p65 and p65 in 6 couples of glioma tissues and 1 couple of normal tissues were detected via western blot analysis for showing the significant tendency. GAPDH was used as cross reference. Data are presented as mean \pm SEM ( $\left.n=3,{ }^{*} \mathrm{P}<0.01\right)$. (C) Immunohistochemical staining of PP1 $\gamma$ and Ki-67 were carried out in 100 glioma specimens. The immunoreactivity increased with the WHO grade of the glioma. Scale bar, $100 \mu \mathrm{m}$. (D) The correlation test showed the strong consistency between PP1 $\gamma$ and Ki-67 (P<0.01). (E and F) High expression of PP1 $\gamma$ was related to low accumulative survival, similarly to Ki-67 (P<0.01). ( $\mathrm{G}$ and $\mathrm{H}$ ) PP1 $\gamma$ was the most highly expressed in U251, followed by U87MG. 
Table I. The correlation between PP1 $\gamma$, and Ki-67 expression and clinicopathological parameters in 100 glioma specimens.

\begin{tabular}{|c|c|c|c|c|c|c|c|}
\hline \multirow[b]{2}{*}{ Variable } & \multirow[b]{2}{*}{ Total } & \multicolumn{2}{|c|}{ PP1 $\gamma$ expression } & \multirow[b]{2}{*}{ P-value } & \multicolumn{2}{|c|}{ Ki-67 expression } & \multirow[b]{2}{*}{ P-value } \\
\hline & & Low & High & & Low & High & \\
\hline \multicolumn{8}{|l|}{ Age } \\
\hline$<40$ & 17 & 12 & 5 & \multirow[t]{2}{*}{0.291} & 12 & 5 & \multirow[t]{2}{*}{0.291} \\
\hline$\geq 40$ & 83 & 46 & 37 & & 46 & 37 & \\
\hline \multicolumn{8}{|l|}{ Grender } \\
\hline Female & 37 & 22 & 15 & \multirow[t]{2}{*}{0.494} & 24 & 13 & \multirow[t]{2}{*}{0.304} \\
\hline Male & 63 & 36 & 27 & & 34 & 29 & \\
\hline \multicolumn{8}{|c|}{ Tumor location } \\
\hline Frontal & 26 & 17 & 9 & \multirow[t]{5}{*}{0.550} & 18 & 8 & \multirow[t]{5}{*}{0.387} \\
\hline Parietal & 25 & 14 & 11 & & 13 & 12 & \\
\hline Occipital & 20 & 10 & 10 & & 10 & 10 & \\
\hline Temporal & 23 & 12 & 11 & & 12 & 11 & \\
\hline Unknown & 6 & 5 & 1 & & 5 & 1 & \\
\hline \multicolumn{8}{|l|}{ Surgery } \\
\hline Biopsy & 17 & 11 & 6 & \multirow[t]{3}{*}{0.824} & 11 & 6 & \multirow[t]{3}{*}{0.779} \\
\hline $\begin{array}{l}\text { Partial } \\
\text { resection }\end{array}$ & 41 & 23 & 18 & & 24 & 17 & \\
\hline $\begin{array}{l}\text { Gross total } \\
\text { resection }\end{array}$ & 42 & 24 & 18 & & 23 & 19 & \\
\hline \multicolumn{8}{|c|}{ Vessel density } \\
\hline Normal & 23 & 16 & 7 & \multirow[t]{2}{*}{0.235} & 15 & 8 & \multirow[t]{2}{*}{0.478} \\
\hline Increase & 77 & 42 & 35 & & 43 & 34 & \\
\hline \multicolumn{8}{|c|}{ Tumor diameter } \\
\hline$<4 \mathrm{~cm}$ & 41 & 24 & 17 & \multirow[t]{2}{*}{0.547} & 24 & 17 & \multirow[t]{2}{*}{0.547} \\
\hline$\geq 4 \mathrm{~cm}$ & 59 & 34 & 25 & & 34 & 25 & \\
\hline \multicolumn{8}{|l|}{ Necrosis } \\
\hline Absence & 40 & 28 & 12 & \multirow[t]{2}{*}{0.077} & 28 & 12 & \multirow[t]{2}{*}{0.063} \\
\hline Presence & 60 & 30 & 30 & & 30 & 30 & \\
\hline \multicolumn{8}{|l|}{ WHO grade } \\
\hline II & 36 & 27 & 9 & \multirow[t]{3}{*}{$0.004^{\mathrm{a}}$} & 28 & 8 & \multirow[t]{3}{*}{$0.001^{\mathrm{a}}$} \\
\hline III & 35 & 21 & 14 & & 21 & 14 & \\
\hline IV & 29 & 10 & 19 & & 9 & 20 & \\
\hline
\end{tabular}

Statistical analyses were performed by the Pearson $\chi^{2}$ test. ${ }^{a} \mathrm{P}<0.05$ was considered statistically significant.

cell lines, U251 and U87MG, for the following experiments, because PP1 $\gamma$ was shown to be the highest expressed in these cells (Fig. $1 \mathrm{G}$ and $\mathrm{H}$ ).

In view of the positive relationship between PP1 $\gamma$ and Ki-67, overexpression of PP1 $\gamma$ was likely to accelerate cell proliferation. To make it clear, we designed a serum-starvation and re-feeding models with U251 and U87MG cell lines. The flow cytometry analysis indicated that when the cells were controlled in the serum deprivation environment for $72 \mathrm{~h}$, the proportion of the cells arrested in the G1 phase increased to 63.00 and $63.09 \%$, respectively. After re-feeding, the proportion of the cells in the G1 phase reduced and that in S phase increased gradually (Fig. 2A, B, E and F). At the same time, we detected the levels of the expression of PP1 $\gamma, p-p 65$ and reported cell proliferation protein markers, such as PCNA, and cyclin D1. Based on the results provided above (Fig. 2C, D, $\mathrm{G}$ and $\mathrm{H}$ ), we could make the tentative conclusion that PP1 $\gamma$ might be related to the proliferation of glioma cells, and that it accelerates the pathological process of glioma.

Downregulation of PPI $\gamma$ inhibits the proliferation of U251 and $U 87 M G$ cell lines in vitro. Since we had uncovered that PP1 $\gamma$ was upregulated in the starve-released cells, it was necessary to verify its characteristics in the silencing of PP1 $\gamma$. 
A

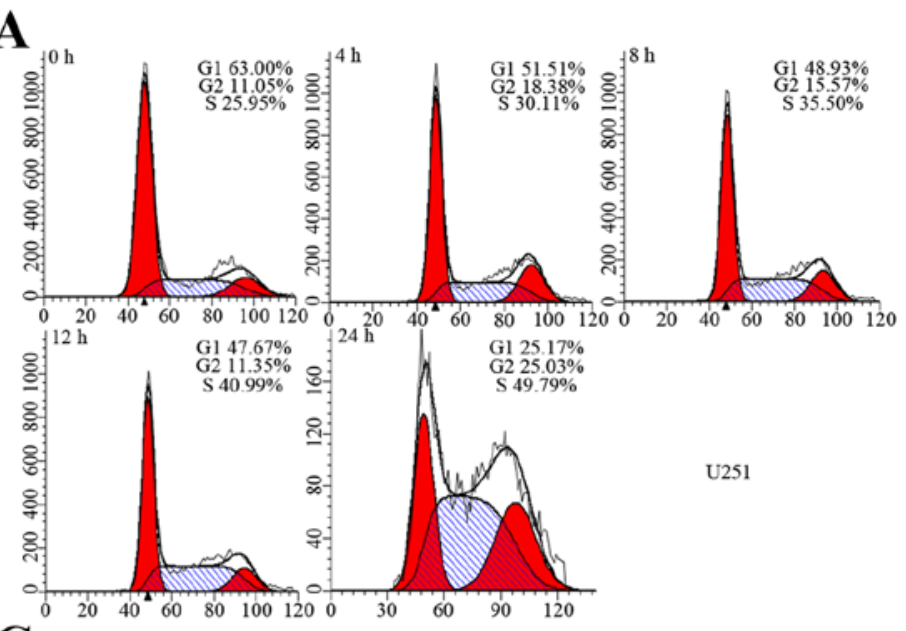

C

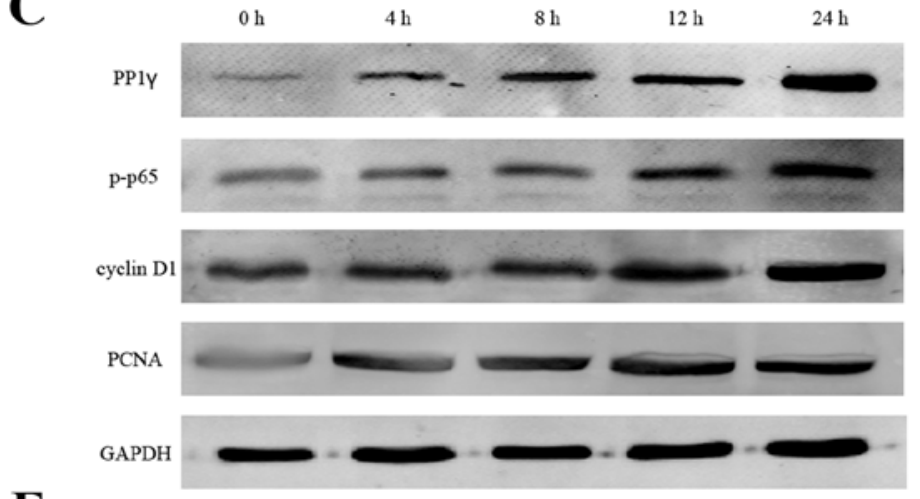

$\mathbf{E}$

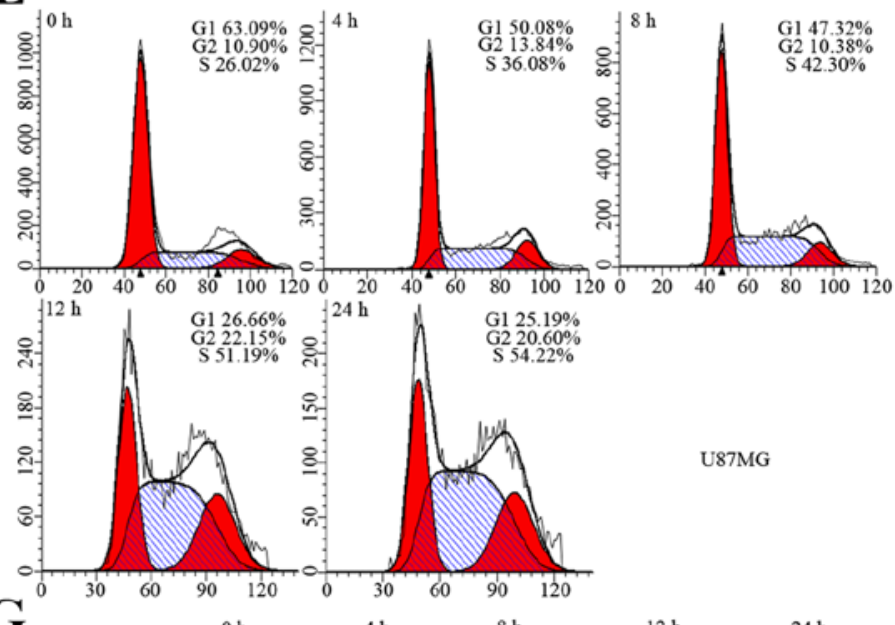

G

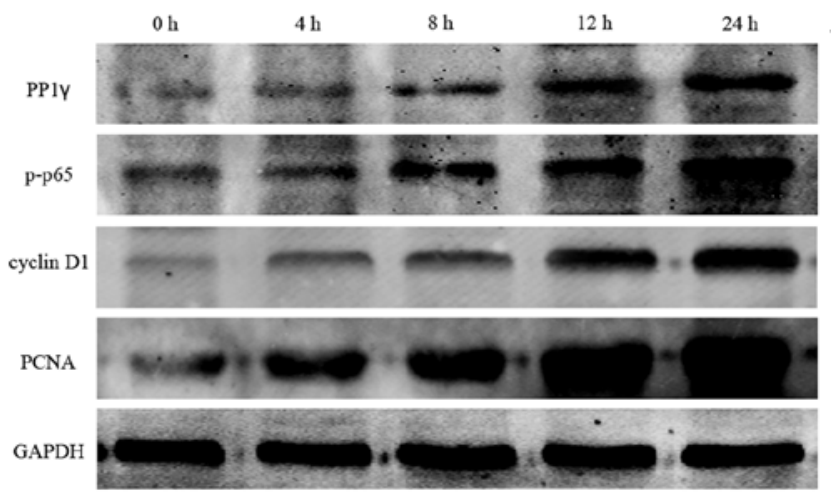

B
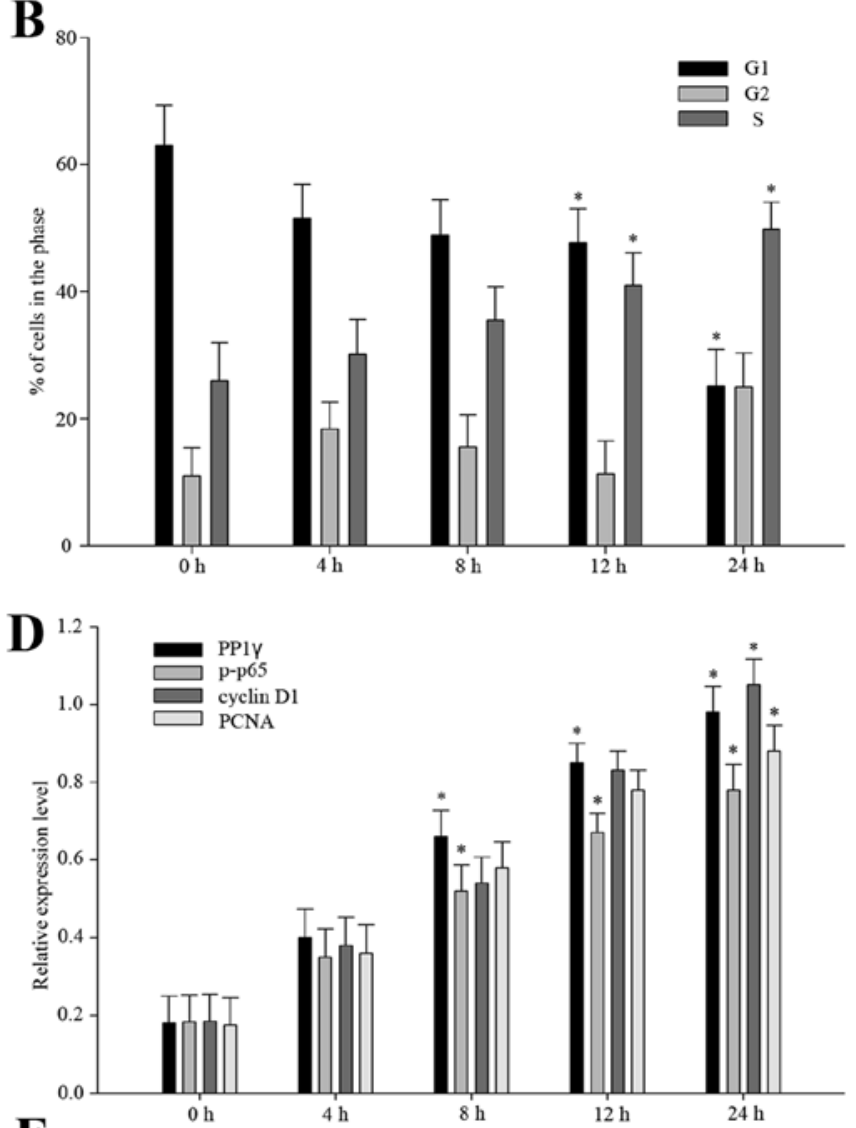

$\mathbf{F}$

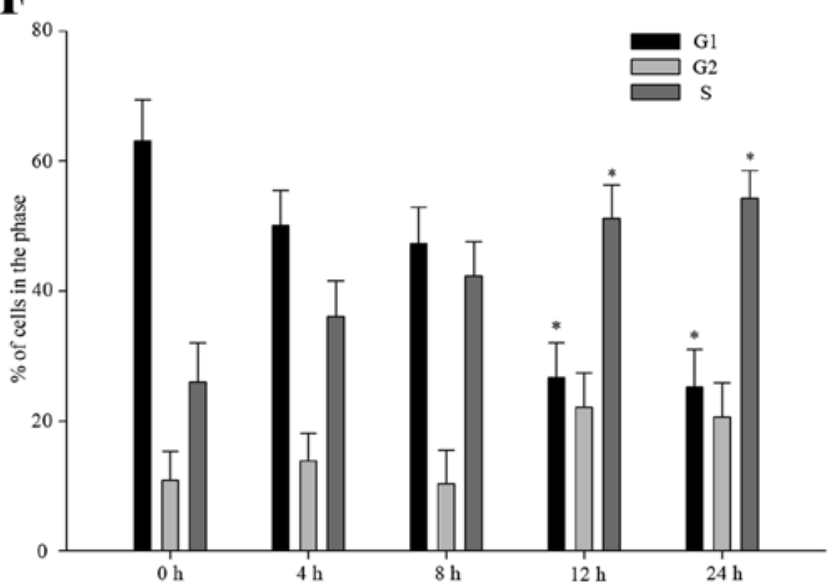

$\mathbf{H}$

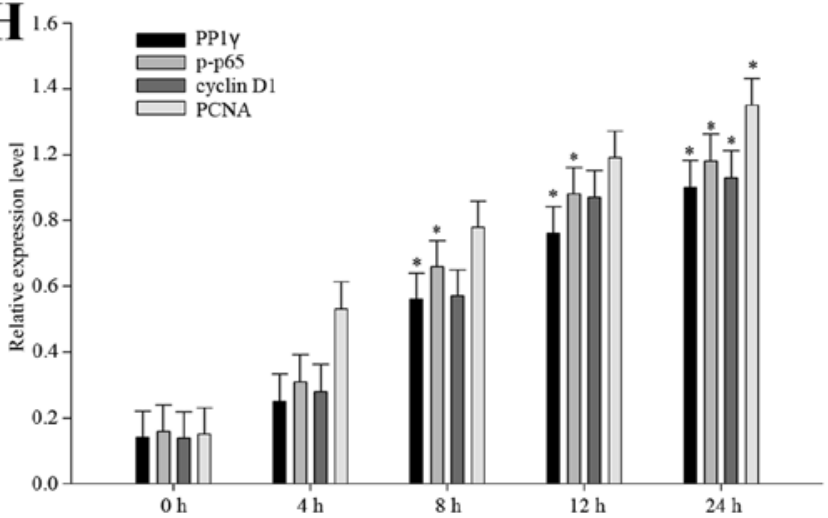

Figure 2. The expression of PP1 $\gamma$ and the different phases of cell cycle in serum-starve and re-feeding models. (A, B, E and F) Flow cytometry showed most of the cells were arrested in G1 phase and the obvious cell cycle progression in U251 and U87MG cells in the process of re-feeding after serum-starvation for $72 \mathrm{~h}$. (C, D, G and H) p-p65 and proliferation makers, PCNA, cyclin D1 had increasing trend with PP1 $\gamma$ at each time-point. GAPDH was used as control protein load. Data are presented as mean $\pm \operatorname{SEM}\left(n=3,{ }^{*} \mathrm{P}<0.01\right.$, compared with control- $\left.0 \mathrm{~h}\right)$. 
Table II. Contribution of various potential prognostic factors to survival by univariate analysis in 100 glioma specimens.

\begin{tabular}{llll}
\hline & & \multicolumn{2}{c}{ Survival status } \\
Characteristics & Total & $<5$ years $\quad \geq 5$ years & P-value \\
\hline
\end{tabular}

\section{Age \\ $<40$}

$\geq 40$

17

83

9

44

8

0.601

Grender

Female

Male

37

63

14

39

23

24

Tumor location

Frontal

Parietal

Occipital

Temporal

Unknown

Surgery

Biopsy

Partial

resection

Gross total

resection

Vessel density

Normal

Increase

13

10

37

Tumor diameter

$<4 \mathrm{~cm}$

$\geq 4 \mathrm{~cm}$

41

59

20

21

26

Necrosis

Absence

Presence

WHO grade

II

III

IV

40

60

18

22

0.223

25

13

12

7

12

3

7

20

20

0.865

0.821

0.054

was compared by western blot analysis (Fig. 3A and B). As shown, PP1 $\gamma$-shRNA\#2 achieved the best knock-down efficiency in U251 cell line, as PP1 $\gamma$-shRNA\#4 to U87MG. We performed flow cytometry analyses to show the proportion of the transfected cells in G1 and S phases (Fig. 3C and D, $\mathrm{P}<0.01$ ). Obviously, on the one hand the cells of G1 phase increased from 48.01 to $59.51 \%$ in U251, 48.34 to $61.65 \%$ in U87MG, on the other hand the cells of $\mathrm{S}$ phase decreased from 35.44 to $23.37 \%$ in U251, 38.19 to $25.82 \%$ in U87MG, which indicated that down-expression of PP $1 \gamma$ delayed the cell cycle. Moreover, we detected the expression of p-p65, p65, IкB $\alpha$, cyclin D1, and PCNA (Fig. 3E and F). According to previous studies, the activation of the NF- $\mathrm{KB}$ signaling cascade results in complete degradation of $\mathrm{I} \kappa \mathrm{B}$, allowing translocation of $\mathrm{NF}-\mathrm{\kappa B}$ to the nucleus, where it induces transcription (23). It revealed the declined expression of PP1 $\gamma$ and p-p65 accompanied by the increased IкB $\alpha$, which meant that PP1 $\gamma$ did play an important role in the cell cycle and cell proliferation via the NF- $\mathrm{KB}$ pathway. To complete the evidence for conclusion, we carried out CCK-8 assay to compare the proliferation of PP1 $\gamma$-depletion cells to the control-shRNA-transfected groups (Fig. 4A and B, P<0.01). The relative absorbance was less than that of the negative-control group. In the colony formation assay, similar difference was observed (Fig. 4C-F, P<0.01). Besides, we extracted the nuclear of PP1 $\gamma$-depletion cells for NF- $\kappa \mathrm{B}$ activity assay. The activity of NF- $\mathrm{KB}$ was obviously declined comparing to negative groups (Fig. $5 \mathrm{~A}$ and $\mathrm{B}, \mathrm{P}<0.01$ ).

Depletion of PPI $\gamma$ reduces $p 65$ transport into the nucleus. Via western blot analysis, we observed the clearly decreased p65 expression in nucleus of PP1 $\gamma$-depletion cells, and its expression in cytoplasm was more than the control groups (Fig. 5C and D). It showed that knocking-down PP1 $\gamma$ actually declined p65 transport across the nuclear envelope. In other words, PP $1 \gamma$ indeed played a role in accelerating the NF- $\kappa B$ pathway, thus enhancing glioma cell proliferation.

\section{Discussion}

Human glioma is the most common type of central nervous system (CNS) malignancy (24). The current standard therapy includes maximal safe resection followed by radiotherapy in combination with temozolomide (25). It is still a typical deadly cancer among the neurological oncology. Malignant glioma cell proliferation and invasion are key stages in cancer progression that affect mortality of the patients (26). Therefore, it is urgent to investigate the underlying molecular pathological mechanism of human glioma. In this study, we presented that PP1 $\gamma$ could be involved in the molecule mechanisms for the proliferation of human glioma, at least partially, via the NF- $\kappa B$ pathway.

Mammals express three PP1 catalytic isoforms, PP1 $\alpha$, PP1 $\gamma$, and PP1 $1 / \sigma$, which show distinct subcellular localization patterns (27). PP1 catalytic isoforms do not exist freely in cells but rather associate with regulatory subunits to form distinct multimeric holoenzymes. In general, PP1 regulatory subunits function as signaling modules by regulating the enzymatic activity or targeting of catalytic subunits to specific substrates (28). According to some research, PP1 $\alpha$ and PP $1 \beta / \sigma$ facilitates pRB-dependent DNA repair in retinoblastoma (29). Besides,
We transfected U251 and U87MG cells with control-shRNA, PP1 $\gamma$-shRNA\#1, PP1 $\gamma$-shRNA\#2, PP1 $\gamma$-shRNA\#3 and PP1 $\gamma$-shRNA\#4, respectively. The efficiency of all the shRNAs 
A
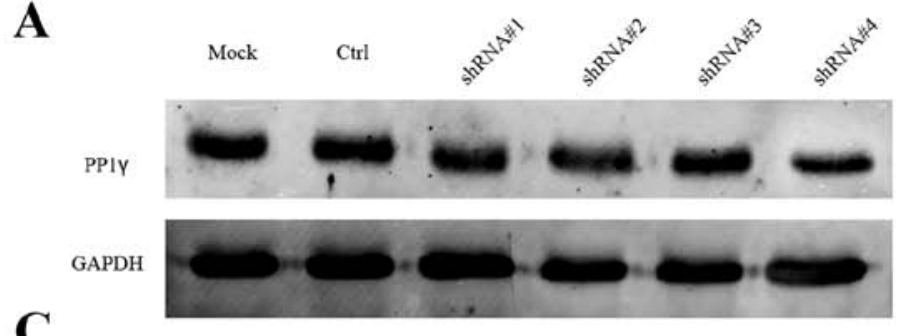

$\mathbf{C}$

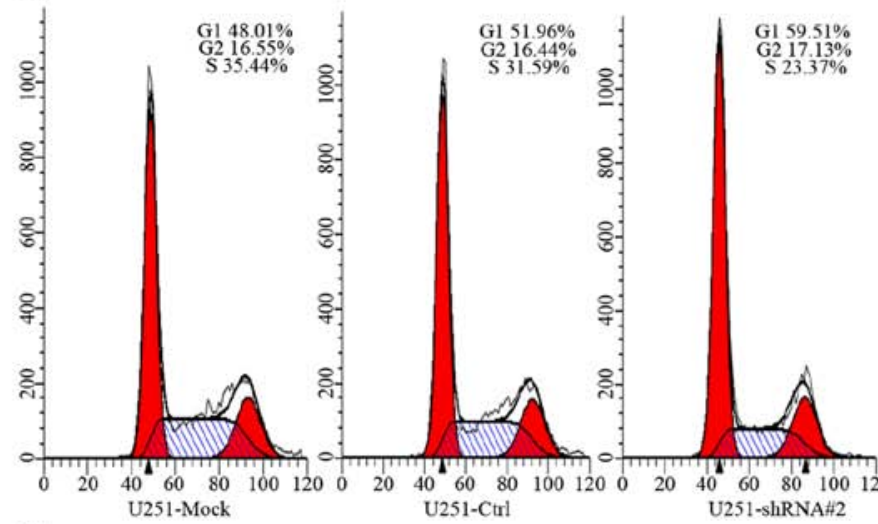

$\mathbf{E}$

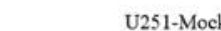

U251-Mock

U251-Ctrl
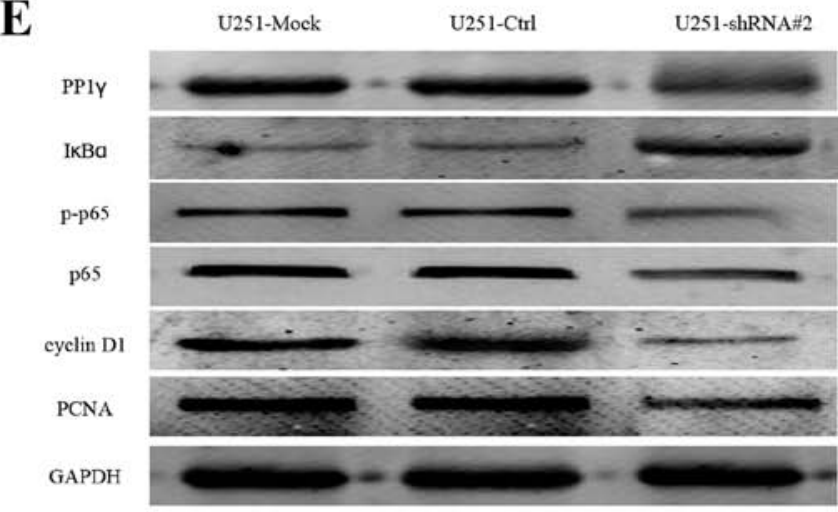

G

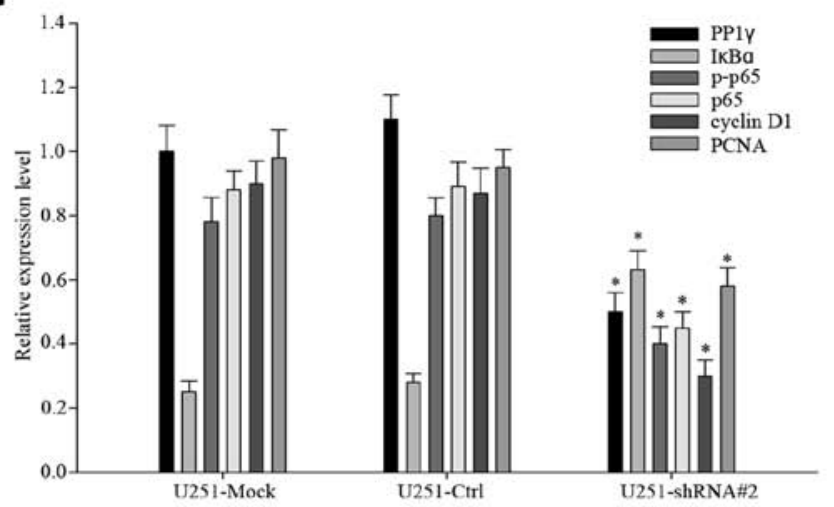

B

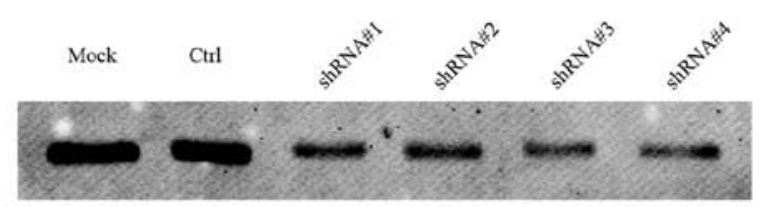

GAPDH

D
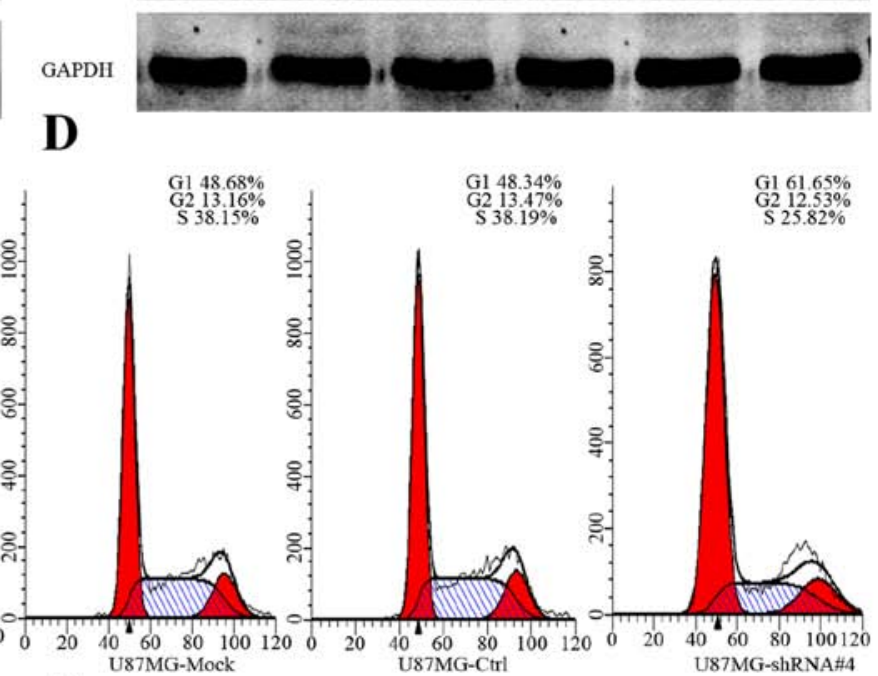

$\mathbf{F}$

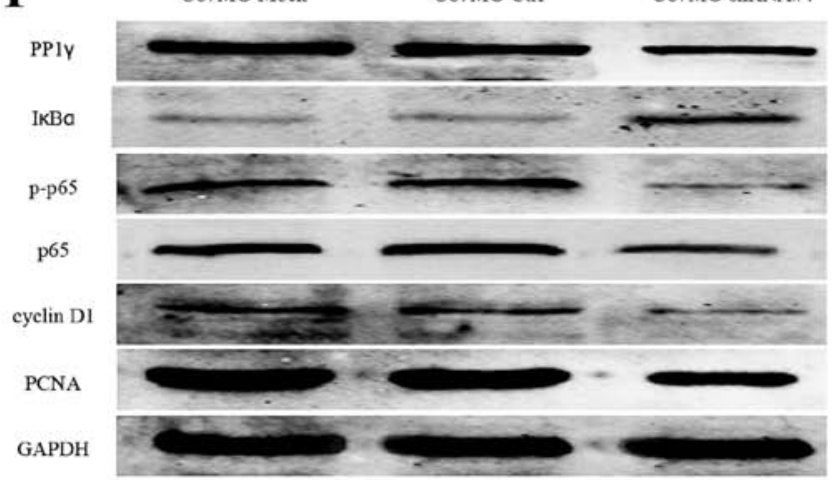

$\mathbf{H}$

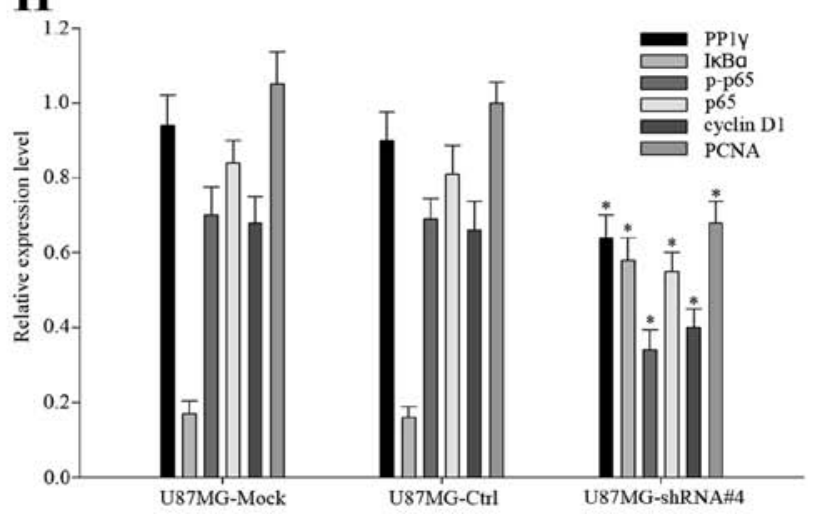

Figure 3. Depletion of PP1 $\gamma$ weakened the ability of proliferation in U251 and U87MG cells. (A and B) The highest level of effectiveness is shRNA\#2 to U251 and shRNA\#4 to U87MG cells. (C and D) 59.51 and $61.65 \%$ of the PP1 $\gamma$-depletion cells were arrested in G1 phase. (E-H) IкB $\alpha, \mathrm{p}-\mathrm{p} 65$, p65, cyclin D1, and PCNA were detected via western blot analysis showing the changing trend as inhibition of proliferation. Data were presented as mean \pm SEM $(n=3$, $P<0.01$, compared to the control groups).

PP1 $\alpha$ has been characterized as an inhibitor of TNFR-induced $\mathrm{NF}-\kappa \mathrm{B}$ signaling (30), suggesting that the PP1 isoforms may be involved in DNA repair in human glioma. However, there is no enough evidence to demonstrate that the two isoforms are involved in the field of cell proliferation.

Protein phosphatase $1 \gamma(\mathrm{PP} 1 \gamma)$ is one of the serine/threonine protein phosphatases in human body which take part in the reversible phosphorylation reaction of nearly $70 \%$ of all eukaryotic proteins (31). It has been demonstrated that PP1 $\gamma$ executes positive regulation in the TRAF6-dependent immune responses (11), in which, $\mathrm{NF}-\kappa \mathrm{B}$ (p65) is activated and translocated into nucleus. The activated $N F-\kappa B$ binds to specific DNA sequences in target genes involving tumor cell proliferation (10). Thus, we investigated whether PP1 $\gamma$ played a role in 
A

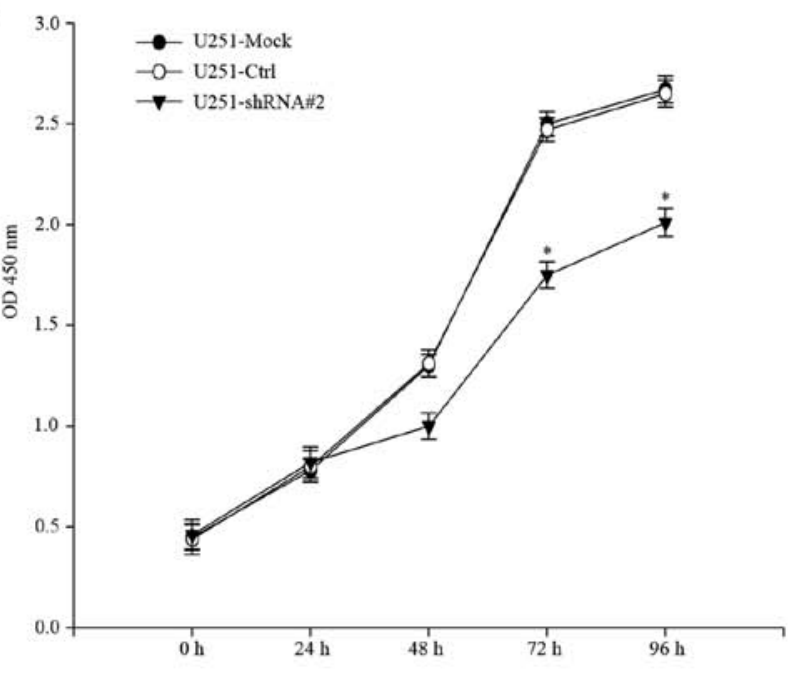

B

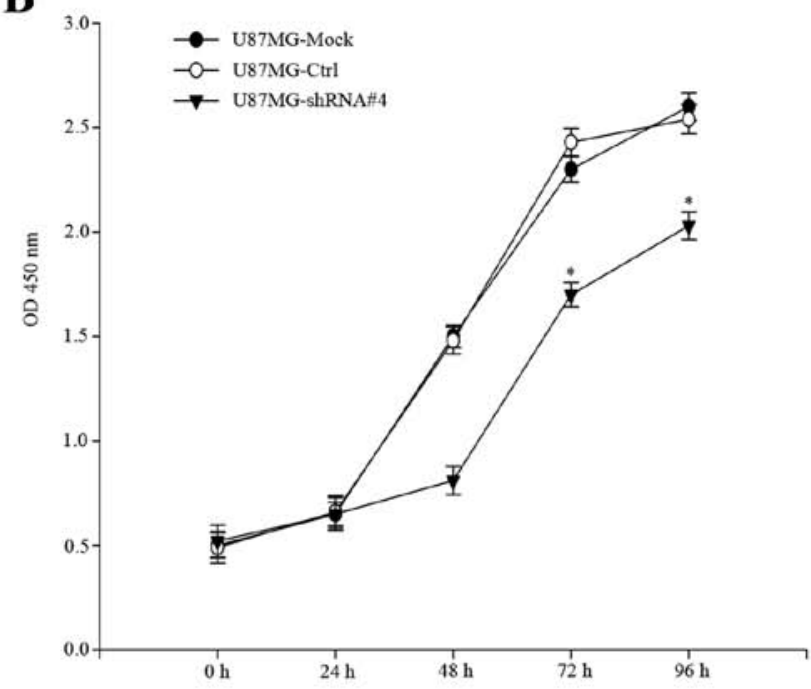

C

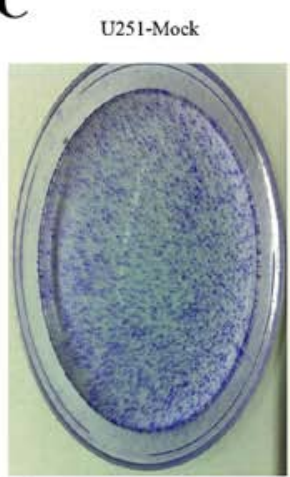

$\mathbf{E}$

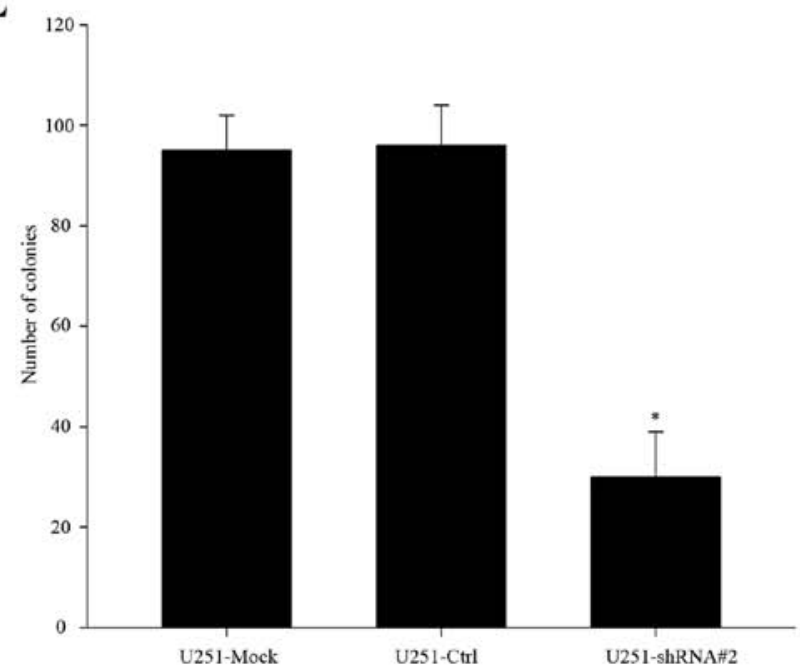

D U87MG-Mock U87MG-Ctrl U87MG-shRNA\#4 
A

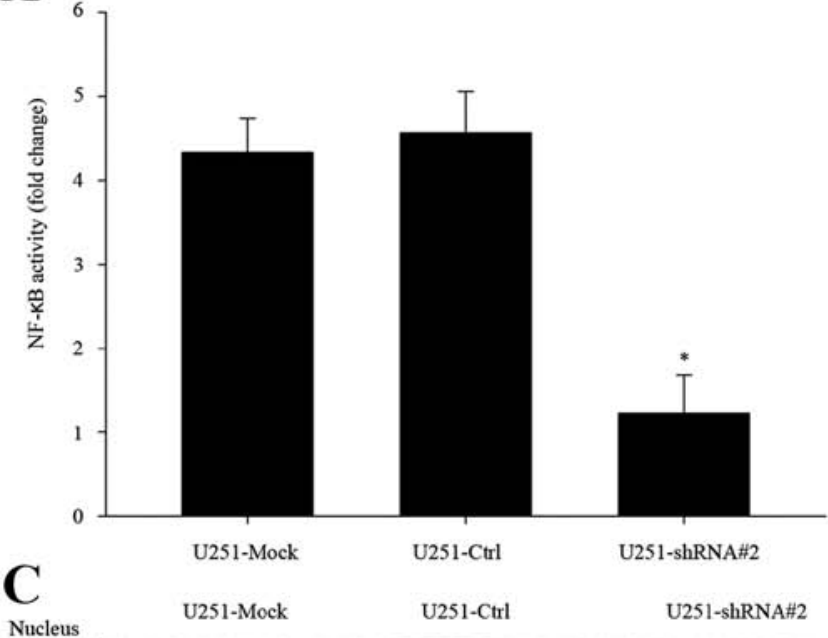

Nucleus

p65

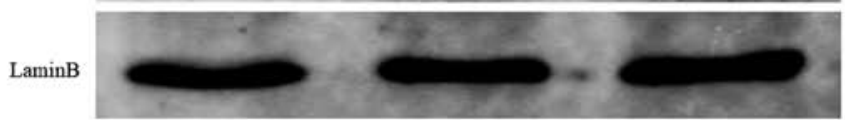

Cytoplasm

p65

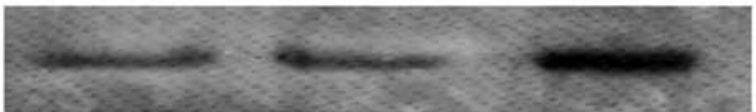

$\alpha$-tubulin

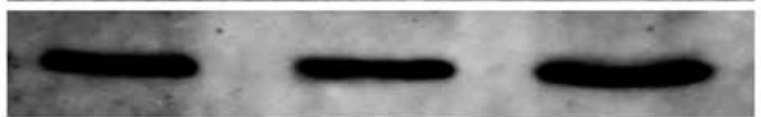

B
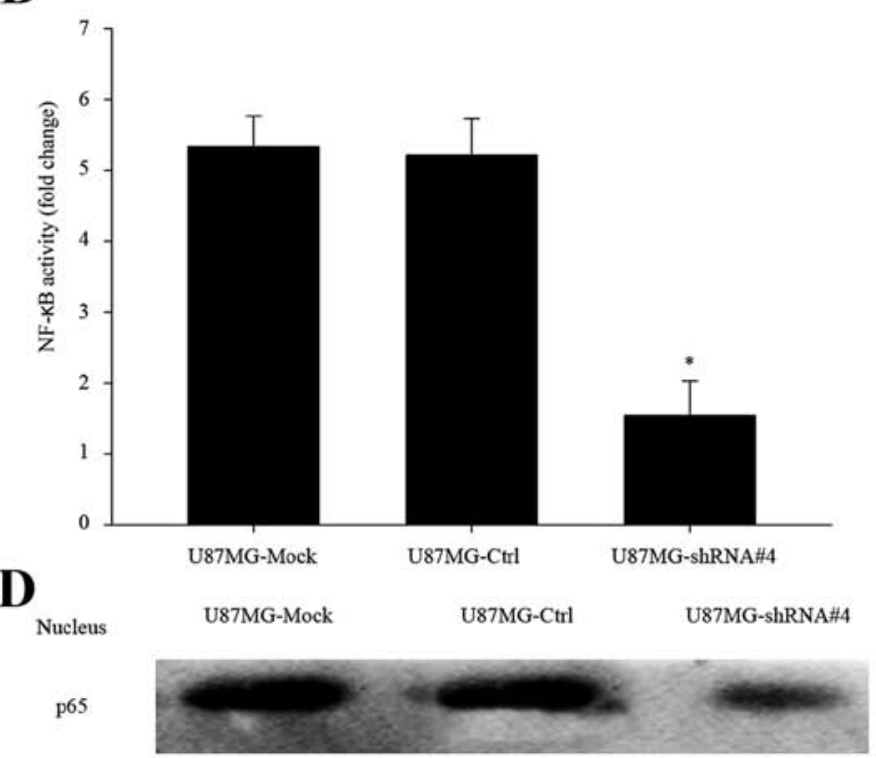

LaminB

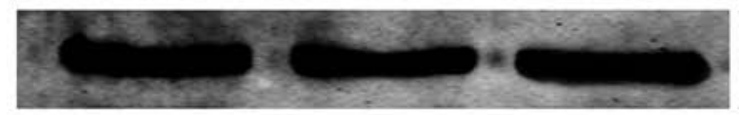

Cytoplasm

p65

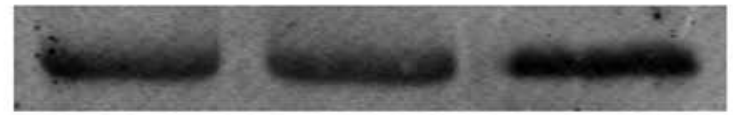

$\alpha$-tubulin

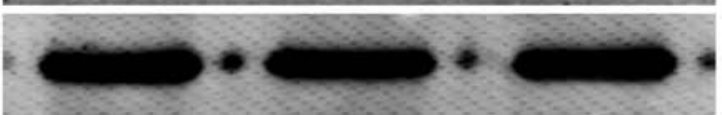

Figure 5. The NF-אB activity was declined in PP1 $\gamma$-depletion U251 and U87MG cells, and the expression of p65 in the nucleus and cytoplasm of the two PP1 $\gamma$ depletion cell models were notably different. (A and B) NF-кB activity assay was carried out in the PP1 $\gamma$-depletion U251 and U87MG cells. Data are presented as mean $\pm \operatorname{SEM}\left(n=3,{ }^{\prime} P<0.01\right)$. (C and D) Via cell fractionation, p65 was found to be decreased in the nucleus of PP1 $\gamma$-depletion U251 and U87MG cells.

PP1 $\gamma$, p-p65 and proliferation markers, cyclin D1, and PCNA, demonstrating its function in proliferation. However, the molecule mechanism of PP1 $\gamma$ was still unclear.

Based on previous studies, PP1 $\gamma$ specifically dephosphorylate a phosphor-site on TRAF6, its E2 enzyme complex, allowing for full E3 ubiquitin ligase activity. Such a dephosphorylation event may expose nearby residues for modification by ubiquitin and enhance the enzymatic activity of TRAF6 (11). Moreover, the ubiquitination of TRAF6 is required for the induction of NF- $\kappa \mathrm{B}$ activation and osteoclastogenesis (12). On the basis of recent studies, we made the hypothesis that PP1 $\gamma$ interacts with TRAF6 via residues 315-354 of the coiled-coil domain and enhances its ubiquitin activity. Then IKK $\gamma$ is activated leading to the degradation of $\mathrm{I} \kappa \mathrm{B} \alpha$, which promotes the phosphorylation of p65 and the translocation into the nucleus. TRAF6 might be the key upstream molecule of p65. In the PP1 $\gamma$-depletion cell models, we observed remarkably reduced expression of PP1 $\gamma$ and p-p65 and increased expression of $\mathrm{I} \kappa \mathrm{B} \alpha$ in the cell lysate comparing to the negative-control groups $(\mathrm{P}<0.01)$. It uncovered the possible inhibition to the $\mathrm{NF}-\kappa \mathrm{B}$ pathway, which needed to be identified.

The activation of $\mathrm{NF}-\kappa \mathrm{B}$ signaling cascade results in complete degradation of $\mathrm{I} \kappa \mathrm{B}$, allowing translocation of $\mathrm{NF}-\kappa \mathrm{B}$ to the nucleus, where it induces transcription (33). Activated $\mathrm{NF}-\kappa \mathrm{B}$ binds to specific DNA sequences in target genes involving tumor cell proliferation, invasion, metastasis, angiogenesis, chemoresistance, radioresistance, inflammation and immune-regulation (10). It means the translocation of p65 is necessary for the activation of transcription. Via western blot analysis, the reduced expression of p65 was detected in cell nucleus comparing to the negative-control groups $(\mathrm{P}<0.01)$. In addition, the inhibition of cell proliferation was observed by flow cytometry analysis of cell cycle, Cell Counting Kit (CCK)-8 assay and colony formation assay. Directly, the NF- $\kappa \mathrm{B}$ activity assay testified the inactivation of PP1 $\gamma$-depletion cells in contract to negative groups $(\mathrm{P}<0.01)$. The evidence was powerful demonstrating that the upregulated PP1 $\gamma$ activated $\mathrm{NF}-\kappa \mathrm{B}$ (p65) and enhanced the translocation into nucleus, leading to cell proliferation in human glioma. Besides, the ubiquitin ligase activity of TRAF6 can be diminished by the absence of PP1 $\gamma$ phosphatase activity (11). Nevertheless, the molecule mechanism is unknown. It is possible that PP1 $\gamma$ may specifically dephosphorylate an unknown inhibitory phosphosite on TRAF6, its E2 enzyme complex, or one of its substrates, allowing for full E3 ubiquitin ligase activity. To demonstrate the hypothesis and explore other possible upstream molecules, more experiments will be carried out in the following research plans.

In conclusion, PP1 $\gamma$ was significantly upregulated in human glioma accompanied by the inhibition of p65 translocation 
into the nucleus. We identified strong positive correlation of the overexpression of PP1 $\gamma, \mathrm{p}-\mathrm{p} 65$, p65 and the WHO grades of human glioma. Moreover, we observed the rising expression trend of $\mathrm{PP} 1 \gamma, \mathrm{p}-\mathrm{p} 65$ and proliferation markers in serum-starved models. The reduced expression of PP1 $\gamma$ and p-p65 and the increased expression of IкB $\alpha$ were detected in cell lysate of PP1 $\gamma$-depletion models comparing to negativecontrol groups. Besides, the decreased expression of p65 was detected in the cell nucleus of PP1 $\gamma$-deleption models. These data are compatible with the hypothesis that increased levels of $\mathrm{PP} 1 \gamma$ promoted cell proliferation through NF- $\mathrm{KB}$ pathway in human glioma. Nevertheless, further research is necessary to elucidate the function of PP1 $\gamma$ in essential biological events and to clarify possible novel therapeutic strategies in human glioma.

\section{Acknowledgements}

This study was supported by National Natural Science Foundation of China (no. 81372687).

\section{References}

1. Deorah S, Lynch CF, Sibenaller ZA and Ryken TC: Trends in brain cancer incidence and survival in the United States: Surveillance, Epidemiology, and End Results Program, 1973 to 2001. Neurosurg Focus 20: E1, 2006.

2. Reardon DA, Herndon JE II, Peters KB, Desjardins A, Coan A, Lou E, Sumrall AL, Turner S, Lipp ES, Sathornsumetee S, et al: Bevacizumab continuation beyond initial bevacizumab progression among recurrent glioblastoma patients. Br J Cancer 107: 1481-1487, 2012.

3. Bertling E, Hotulainen P, Mattila PK, Matilainen T, Salminen M and Lappalainen P: Cyclase-associated protein 1 (CAP1) promotes cofilin-induced actin dynamics in mammalian nonmuscle cells. Mol Biol Cell 15: 2324-2334, 2004.

4. Maher EA, Furnari FB, Bachoo RM, Rowitch DH, Louis DN, Cavenee WK and DePinho RA: Malignant glioma: Genetics and biology of a grave matter. Genes Dev 15: 1311-1333, 2001.

5. Zhuang W, Qin Z and Liang Z: The role of autophagy in sensitizing malignant glioma cells to radiation therapy. Acta Biochim Biophys Sin (Shanghai) 41: 341-351, 2009.

6. Wen PY and Kesari S: Malignant gliomas in adults. N Engl J Med 359: 492-507, 2008

7. Cohen PT: Protein phosphatase 1 - targeted in many directions. J Cell Sci 115: 241-256, 2002.

8. Varmuza S, Jurisicova A, Okano K, Hudson J, Boekelheide K and Shipp EB: Spermiogenesis is impaired in mice bearing a targeted mutation in the protein phosphatase 1cgamma gene. Dev Biol 205: 98-110, 1999.

9. Bargou RC, Emmerich F, Krappmann D, Bommert K, Mapara MY, Arnold W, Royer HD, Grinstein E, Greiner A, Scheidereit C, et al: Constitutive nuclear factor-kappaB-RelA activation is required for proliferation and survival of Hodgkin's disease tumor cells. J Clin Invest 100: 2961-2969, 1997.

10. Borrello MG, Degl'Innocenti D and Pierotti MA: Inflammation and cancer: The oncogene-driven connection. Cancer Lett 267: 262-270, 2008

11. Opaluch AM, Schneider M, Chiang CY, Nguyen QT, Maestre AM, Mulder LC, Secundino I, De Jesus PD, König R, Simon V, et al: Positive regulation of TRAF6-dependent innate immune responses by protein phosphatase PP1- $\gamma$. PLoS One 9: e89284, 2014.

12. Ang E, Pavlos NJ, Rea SL, Qi M, Chai T, Walsh JP, Ratajczak T, Zheng $\mathrm{MH}$ and Xu J: Proteasome inhibitors impair RANKLinduced NF-kappaB activity in osteoclast-like cells via disruption of p62, TRAF6, CYLD, and IkappaBalpha signaling cascades. J Cell Physiol 220: 450-459, 2009.

13. Yang Y, Blair HC, Shapiro IM and Wang B: The proteasome inhibitor carfilzomib suppresses parathyroid hormone-induced osteoclastogenesis through a RANKL-mediated signaling pathway. J Biol Chem 290: 16918-16928, 2015.
14. Vallabhapurapu S and Karin M: Regulation and function of NF-kappaB transcription factors in the immune system. Annu Rev Immunol 27: 693-733, 2009.

15. Bettoun DJ, Buck DW II, Lu J, Khalifa B, Chin WW and Nagpal S: A vitamin D receptor-Ser/Thr phosphatase-p70 S6 kinase complex and modulation of its enzymatic activities by the ligand. J Biol Chem 277: 24847-24850, 2002.

16. Wang Y, Liu F, Mao F, Hang Q, Huang X, He S, Wang Y, Cheng C, Wang $\mathrm{H}, \mathrm{Xu} \mathrm{G}$, et al: Interaction with cyclin $\mathrm{H} /$ cyclin-dependent kinase $7(\mathrm{CCNH} / \mathrm{CDK} 7)$ stabilizes $\mathrm{C}$-terminal binding protein 2 (CtBP2) and promotes cancer cell migration. J Biol Chem 288: 9028-9034, 2013.

17. Tao T, Cheng C, Ji Y, Xu G, Zhang J, Zhang L and Shen A: Numbl inhibits glioma cell migration and invasion by suppressing TRAF5-mediated NF- $\kappa$ B activation. Mol Biol Cell 23: 2635-2644, 2012.

18. Huang X, Liu F, Zhu C, Cai J, Wang H, Wang X, He S, Liu C, Yao L, Ding Z, et al: Suppression of KIF3B expression inhibits human hepatocellular carcinoma proliferation. Dig Dis Sci 59: 795-806, 2014.

19. Ding Z, Liu X, Liu Y, Zhang J, Huang X, Yang X, Yao L, Cui G and Wang D: Expression of far upstream element (FUSE) binding protein 1 in human glioma is correlated with c-Myc and cell proliferation. Mol Carcinog 54: 405-415, 2015.

20. Lin SY, Makino K, Xia W, Matin A, Wen Y, Kwong KY, Bourguignon L and Hung MC: Nuclear localization of EGF receptor and its potential new role as a transcription factor. Nat Cell Biol 3: 802-808, 2001.

21. Giri DK, Ali-Seyed M, Li LY, Lee DF, Ling P, Bartholomeusz G, Wang SC and Hung MC: Endosomal transport of ErbB-2: Mechanism for nuclear entry of the cell surface receptor. Mol Cell Biol 25: 11005-11018, 2005.

22. Liu Y, Wang Y, Cheng C, Chen Y, Shi S, Qin J, Xiao F, Zhou D, $\mathrm{Lu} \mathrm{M}, \mathrm{Lu} \mathrm{Q}$, et al: A relationship between p27 (kip1) and Skp2 after adult brain injury: Implications for glial proliferation. J Neurotrauma 27: 361-371, 2010.

23. Ahn KS, Sethi G and Aggarwal BB: Nuclear factor-kappa B: From clone to clinic. Curr Mol Med 7: 619-637, 2007.

24. Ferguson SD: Malignant gliomas: Diagnosis and treatment. Dis Mon 57: 558-569, 2011.

25. Stupp R, Hegi ME, van den Bent MJ, Mason WP, Weller M, Mirimanoff RO and Cairncross JG; European Organisation for Research and Treatment of Cancer Brain Tumor and Radiotherapy Groups; National Cancer Institute of Canada Clinical Trials Group: Changing paradigms - an update on the multidisciplinary management of malignant glioma. Oncologist 11: 165-180, 2006.

26. Qi S, Song Y, Peng Y, Wang H, Long H, Yu X, Li Z, Fang L, Wu A, Luo W, et al: ZEB2 mediates multiple pathways regulating cell proliferation, migration, invasion, and apoptosis in glioma. PLoS One 7: e38842, 2012.

27. Lee JH, You J, Dobrota E and Skalnik DG: Identification and characterization of a novel human PP1 phosphatase complex. J Biol Chem 285: 24466-24476, 2010.

28. Virshup DM and Shenolikar S: From promiscuity to precision: Protein phosphatases get a makeover. Mol Cell 33: 537-545, 2009.

29. Lin CY, Tan BC, Liu H, Shih CJ, Chien KY, Lin CL and Yung BY: Dephosphorylation of nucleophosmin by PP1 $\beta$ facilitates $\mathrm{pRB}$ binding and consequent E2F1-dependent DNA repair. Mol Biol Cell 21: 4409-4417, 2010.

30. Li HY, Liu H, Wang CH, Zhang JY, Man JH, Gao YF, Zhang PJ, Li WH, Zhao J, Pan X, et al: Deactivation of the kinase IKK by CUEDC2 through recruitment of the phosphatase PP1. Nat Immunol 9: 533-541, 2008.

31. Olsen JV, Vermeulen M, Santamaria A, Kumar C, Miller ML, Jensen LJ, Gnad F, Cox J, Jensen TS, Nigg EA, et al: Quantitative phosphoproteomics reveals widespread full phosphorylation site occupancy during mitosis. Sci Signal 3: ra3, 2010.

32. Radner H, Blümcke I, Reifenberger G and Wiestler OD: The new WHO classification of tumors of the nervous system 2000. Pathology and genetics. Pathologe 23: 260-283, 2002 (In German).

33. Ahn KS and Aggarwal BB: Transcription factor NF-kappaB: A sensor for smoke and stress signals. Ann NY Acad Sci 1056: 218-233, 2005. 